\title{
ABOLIÇÃO NO BRASIL: RESISTÉNCIA ESCRAVA, INTELECTUAIS E POLÍTICA (1870-1888)
}

\author{
POR
}

RICARDO SALLES

Universidade Federal do Estado do Rio de Janeiro-UniRio

A Abolição da Escravidão no Brasil coloca as seguintes questões históricas: qual o caráter social do abolicionismo? Qual seu sentido histórico? Foi uma revolução ou apenas um lance na transição para o capitalismo no país? Que interesses defendia o movimento abolicionista? Que grupos sociais protagonizaram o movimento? Qual o papel dos escravos no processo? O que defendiam e quem representavam os intelectuais abolicionistas? São estas indagações que guiam esse artigo no sentido de pensar a relação entre o lugar dos intelectuais abolicionistas e as possibilidades e os limites de formação, ou o «acontecimento» da população escrava e liberta enquanto uma classe nacional no período final da escravidão no Brasil.

Palavras chave: Segunda escravidão, abolicionismo, Brasil, intelectuais, classes sociais.

O Brasil - trata-se de um lugar comum que nunca é demais repetir- foi o último país ocidental a abolir a escravidão, e não sem muita luta e pressão. Não se pode e não se deve separar a história da abolição no Brasil da história da abolição no mundo atlântico, iniciada praticamente um século antes. A distância de cerca de um século a separar as lutas pela extinção do tráfico internacional de escravos na Inglaterra e a abolição em São Domingos, em fins do século XVIII, e a abolição no Brasil não se deve, contudo, a um atraso de adaptação do país aos tempos modernos. A escravidão brasileira —e também a norte-americana e a cubana - do século XIX foi, antes de tudo, criação e criadora da modernidade contemporânea do sistema-mundo dominado pelo advento do capitalismo industrial. Como tal, e assim como este, conviveu, desde seu despertar, com forte e crescente oposição social e mesmo contestação política. 
Entre 1776 e 1848, o mundo ocidental em suas duas margens atlânticas, viveu uma «era de revoluções» ${ }^{1}$. Revoluções políticas puseram abaixo o Antigo Regime europeu e seu correlato americano, o Antigo Sistema Colonial. Movimentos sociais e políticos de trabalhadores passaram a demandar liberdade civil, política e igualdade social, e, entre outras reformas, a abolição do tráfico internacional de escravos e, pouco depois, da própria escravidão. Na Américas, onde se multiplicavam rebeliões escravas, particularmente no Caribe, uma delas, a revolução dos escravos e negros e mestiços livres da colônia francesa de Saint-Domingue, a mais rica de todas no mundo, foi a primeira vitoriosa na História. A Revolução Haitiana abriu um processo histórico em que, no próximo meio século, a escravidão foi abolida, de um só golpe ou por medidas graduais, por iniciativa de governos ou por pressão popular e mesmo dos próprios escravos, em diferentes regiões da América. A coincidência e a articulação entre a abolição e os processos de independência nacional da grande maioria das colônias européias na América levaram o historiador britânico Robin Blackburn a designar todo o processo de derrubada do escravismo colonial ${ }^{2}$. A escravidão pareceu, então, para muitos contemporâneos, e também para muitos estudiosos posteriores, como uma instituição do passado, em vias de desaparecimento ou fadada a desaparecer. Escravidão e civilização — noção que, neste momento, era acrescida de um sentido ligado ao progresso tecnológico e econômico e a uma série de valores associados, como a liberdade civil e de opinião- pareciam antípodas.

Entretanto, neste mesmo momento histórico, em íntima conexão com o desenvolvimento do mercado mundial capitalista, nos Estados do Sul dos Estados Unidos, no Império do Brasil e na colônia espanhola de Cuba, não só a instituição servil foi mantida, como se expandiu como nunca. Nos dois primeiros casos, esta expansão constituiu, parcial ou integralmente, a base material da construção dos Estados nacionais nestas regiões. No Sul dos Estados Unidos, esta segunda escravidão, como a denominou o historiador norte-americano Dale Tomich, uma vez extinto o tráfico internacional em 1808, foi alimentada pelo crescimento vegetativo da população escrava. Em Cuba e no Brasil, pelo contrário, ela foi sustentada por um tráfico internacional revigorado, efetivamente extinto apenas em 1850 no Brasil e em 1866 na colônia espanhola ${ }^{3}$.

Ainda que em Cuba a segunda escravidão tenha se afirmado a partir da renovação de sua condição colonial, no Brasil e nos Estados Unidos, ela foi, an-

1 Sigo, nos próximos parágrafos, com pequenas modificações, o exposto em Salles, 2008: 43 ss.

2 Blackburn, 2002.

3 Tomich, 2004: esp. cap. 2. 
tes de tudo, uma escravidão nacional, no sentido que sua constituição está na raiz e dependeu, em larga medida, da formação dos Estados nacionais ${ }^{4}$. Tal convivência entre o processo de destruição do escravismo colonial e o processo de construção do escravismo nacional, dentro de um mesmo quadro internacional, tanto do ponto de vista econômico quanto social, político e cultural, trouxe uma importante conseqüência para as regiões que se aferraram à instituição servil e a desenvolveram como nunca antes na história. Nessas áreas, o novo impulso escravista conviveu permanentemente com uma tensão antiescravista, tanto do ponto de vista interno quanto do ponto de vista internacional $^{5}$.

Nos Estados do Sul dos Estados Unidos, esta tensão foi vivenciada quase que inteiramente como um problema de política doméstica, uma vez que era o resultado direto da convivência com uma opinião pública antiescravista e logo abolicionista que se desenvolvia nos estados nortistas. No Império do Brasil - onde uma opinião pública abolicionista só começou a tomar corpo a partir de meados da década de 1860 - a tensão resultou, ao menos até 1850, da pressão inglesa pela extinção do tráfico internacional de escravos. Com a extinção do tráfico nesta data, houve um esvaziamento desta tensão, que só começou a se delinear, agora a partir de forças internas, mesmo que deflagradas, em parte, pelo resultado da Guerra Civil Norte-americana, a partir de meados da década de 1860 e, mais especificamente, a partir de 1871, quando os debates parlamentares em torno da lei que decretava a liberdade do ventre da mulher escrava reabriram a questão.

Entretanto, pode-se dizer que, do ponto de vista interno, a tensão antiescravista repercutia no interior do próprio campo intelectual e político imperial, desde suas origens na década de 1820. A escravidão era tema ineludível. Fazia parte do repertório de assuntos que, de alguma maneira, relacionavam-se com as questões do século, tais como o liberalismo, o governo representativo, a civilização e o progresso, os movimentos sociais e, evidentemente, a ordem e a liberdade. Este fato era exacerbado pela dimensão cosmopolita do campo intelectual brasileiro, marcado, ao mesmo tempo, por uma grande distância or-

4 Sobre os processos escravistas em Cuba e no Brasil, principalmente em relação ao encaminhamento da abolição do tráfico internacional de escravos e da abolição da escravidão, ver Schmidt-Nowara, 2008: 101-119. Sobre os processos políticos da primeira metade do século XIX e a questão da escravidão, Marquese, Berbel e Parron, 2010.

5 Celso Castilho, analisando o processo abolicionista brasileiro, particularmente na província de Pernambuco, distingue entre anti-escravismo, quando se tratou apenas de opiniões contra a escravidão, emancipacionismo, quando se tratou de políticas de abolição gradual, e abolicionismo, quando houve a proposta de abolição completa. Cf. Castilho, 2008: vii-viii. 
gânica no que tange aos grupos subalternos da sociedade, em especial, os escravos, e por sua polarização pelos centros intelectuais internacionais ${ }^{6}$. Dessa forma, a tensão antiescravista passava pelo interior do próprio Estado nacional, através de suas instituições e agentes, assim como através do espaço público, envolvendo intelectuais, políticos, escritores, jornalistas, a imprensa, associações e demais instituições.

Esta tensão antiescravista repercutia ainda sobre um quadro de resistência escrava endêmica, marcado, no entanto, por crescente e novo protagonismo do cativo nas suas relações com os senhores e outros setores sociais na Era das Revoluções?. É difícil medir quando, quanto e se houve mesmo ou não o aumento no número de rebeliões e outros atos de resistência escrava neste período histórico de destruição do escravismo colonial e construção do escravismo nacional. É constatável, no entanto, que tais atos, a partir de princípios do século XIX, se revestiram de características até então desconhecidas. Eles ocorreram em um período de intensas disputas e transformações sociais e políticas nas sociedades ocidentais em geral e nas sociedades escravistas em particular. Nesta época, estavam em disputa diferentes concepções e propostas de direitos políticos e sociais envolvendo amplos setores da sociedade. Este novo contexto foi percebido e incorporado, em maior ou menor grau, por senhores e escravos em seus enfrentamentos cotidianos e em suas lutas abertas, envolvendo grandes fugas, rebeliões e choques armados coletivos. Esta percepção do novo significado das lutas - e aqui seria rigorosamente apropriado o emprego da expressão luta de classes, termo cujo emprego se generalizou exatamente neste momento histórico - implicou em um novo papel do escravo como agente protagonista das sociedades em que vivia e, principalmente, como protagonista dessas lutas por direitos e, a palavra do momento, liberdade.

A Abolição da Escravidão no Brasil, entretanto, só ocorreu em 1888, depois de um intenso e crescente movimento abolicionista que começou a tomar corpo no início da década de 1880. Tanto a Abolição quanto, especificamente, o movimento abolicionista têm colocado um problema histórico que ainda se encontra em aberto para a historiografia do período. Resumida e esquematicamente, podemos sintetizar este problema com as seguintes questões: qual o caráter social do abolicionismo? Qual seu sentido histórico? Foi uma revolução ou apenas um lance na transição para o capitalismo no país? Que interesses defendia o movimento abolicionista? Que grupos sociais protagonizaram o movimento? Qual o papel dos escravos no processo? O que defendiam e quem

6 Aqui, inspiro-me em Gramsci que assinalou a característica dos intelectuais italianos como uma concentração funcional de cosmopolitismo. Cf. Gramsci, 1999, 1: 429.

7 A idéia de resistência endêmica é de Stuart Schwartz, 1995. 
representavam os intelectuais abolicionistas? Estas e outras indagações permitem levantar algumas hipóteses —e este é o objetivo principal desse textopara pensar a relação entre o lugar dos intelectuais abolicionistas e as possibilidades de formação, ou o «acontecimento», para seguir a terminologia thompsoniana, da população escrava e liberta enquanto uma classe nacional no período final da escravidão no Brasil. Em caráter secundário e na medida em que realiza uma análise histórica concreta, estas hipóteses permitem também uma reflexão de natureza teórica sobre os conceitos de classe, relações sociais de força e intelectuais a partir de sua matriz de formulação gramsciana e sua relação com a questão da agência escrava, que tem sido a pedra de toque da historiografia brasileira recente sobre a escravidão.

$$
* \quad * \quad *
$$

Talvez nenhum outro historiador contemporâneo tenha sido mais influente junto a esta historiografia do que Edward Palmer Thompson. Em artigo de 2006, os historiadores sociais brasileiros Flávio dos Santos Gomes e Antonio Luigi Negro utilizaram-se de um conhecido texto de Thompson em que este analisa o século XVIII inglês na perspectiva da luta de classes, mesmo que os agentes históricos não se vissem e não se identificassem enquanto classes. Para Thompson, a classe pode ser entendida tanto como uma formação histórica empírica quanto como uma categoria heurística ${ }^{8}$. Por isso seria válido falar de luta de classes na sociedade inglesa do século XVIII, mesmo que estas últimas não existissem empiricamente. Haveria uma maior amplitude do conceito de luta de classes nas sociedades em que as classes não teriam correspondência empírica — como nas sociedades capitalistas do século XIX- ou teriam apenas uma correspondência empírica rarefeita ${ }^{9}$. De acordo com Thompson, analisando as lutas entre a gentry e a plebe no século XVIII britânico, o fato de não podermos observar «formações de classe "maduras" (quer dizer, conscientes e historicamente desenvolvidas) com suas expressões ideológicas e institucionais, não quer dizer que o que se expresse de modo menos decisivo não seja classe $\rangle^{10}$. Para os historiadores brasileiros, algo semelhante poderia ser observado para as lutas dos escravos e de uma classe trabalhadora em formação no período final da escravidão no Brasil ${ }^{11}$.

\footnotetext{
8 Thompson, 1989: 36-37.

9 Gomes e Negro, 2006: 217-240, 221-222, nota 7.

10 Thompson, 1989: 39.

11 Esse tema foi retomado e ampliado no trabalho de Mattos, 2008.
} 
A vereda é promissora e retornaremos a ela adiante. No momento, vou me deter em algumas considerações de ordem teórica sobre o uso de Thompson e a questão da agência escrava. E para isso vou me valer de Antonio Gramsci.

Não cabe dúvida que o escravo foi um agente histórico, que contribuiu para moldar o mundo em que viveu e que participou ativamente de sua destruição. As teorias do "escravo coisa», animalizado e desprovido de vontade, estão definitiva e devidamente sepultadas. Entretanto, esta constatação de ordem genérica não esgota, mas apenas abre a questão da luta de classes na sociedade escravista. É preciso qualificar o que foram essas lutas em diferentes momentos históricos; analisar seu alcance, seus objetivos, suas possibilidades, seus resultados e suas conseqüências. Isto deve ser feito, no caso brasileiro, especialmente para o período em que a conjuntura política se acelerou e se colocou a bandeira política da abolição da escravidão, isto é, entre 1879 e 1888 . No fundo, com essa proposição o que se trata é de buscar qualificar a expressão utilizada por Thompson, «aquilo que se expressa de modo menos decisivo...». Deixando de lado o explícito termo de comparação com as lutas operárias do século XIX, tomadas como modelo pelo historiador inglês, trata-se de avaliar a efetividade, o alcance, os objetivos, a organicidade interna, etc., dessas expressões, sejam elas menos ou mais decisivas. Que as ações dos grupos subalternos afetam os grupos dominantes, não há dúvida. Tampouco há dúvida de que, por isso mesmo, ações e lutas fragmentadas dos grupos subalternos, antes relegadas a um segundo plano, ou sequer consideradas, ganham nova importância e nos ajudam a entender como se processam aquilo que Gramsci denominou de «transformações moleculares», que terminam por repercutir nas esferas de poder mais amplas da sociedade ${ }^{12}$. Para Gramsci, a «história dos grupos subalternos é necessariamente desagregada e episódica», e, mesmo que em suas práticas eles tendam a se unificar, essa tendência «é continuamente rompida pela iniciativa dos grupos dominantes» (que por isso mesmo, ao serem bem sucedidos neste intento, são dominantes). A tendência à unificação desses grupos subalternos em sua atividade histórica só pode, de fato, ser demonstrada após o encerramento de um ciclo histórico, «se este se encerra com

12 São diversas as passagens nos Cadernos do cárcere que se referem a transformações, processos, mudanças moleculares. Essas passagens têm significados diferentes, dizendo respeito ora a processos intelectuais, materiais ou sociais, algumas vezes de natureza individual, outras de natureza individual. No entanto, o sentido é quase sempre o de processos cumulativos, que se dão em escala reduzida e dispersa, relativamente inconscientes e que contribuem para mudanças perceptíveis no plano geral, cultural, formal e institucional. Cf., por exemplo, Caderno 1, seção 44, p. 41 e ss.; Caderno 7, seções 43 e 44, p. 892 e ss.; Caderno 8, seções 191 e 195, p. 1056 e pp. 1057-58; Caderno p, seção 89, p. 1152; Caderno 15 (II), seção 9: 1762 e ss.; Caderno 22, seções 1 e 3: 2139 e ss.; 2147 e ss. (Quaderni del carcere, Edizione critica). 
sucesso. Os grupos subalternos sofrem sempre a iniciativa dos grupos dominantes, mesmo quando se rebelam e se insurgem...». Mesmo uma vitória permanente não romperia imediatamente essa subordinação, como o demonstrariam os episódios da Revolução Francesa, pelo menos até 1830. Por isso mesmo, isto é, pelo caráter subordinado de suas atividades, «todo traço de iniciativa autônoma por parte dos grupos subalternos deve ser de valor inestimável para o historiador integral.... $\rangle^{13}$.

O ponto, no caso específico das lutas escravas, é ainda mais decisivo. Trata-se de avaliar qual sua condição de acumulação de forças, morais e materiais; sua condição de passar para momentos além dos limites dos embates imediatos. Limites impostos, em larga medida, pelas próprias condições do cativeiro, extremamente desfavoráveis aos escravos e sempre reiteradas pela ação dos senhores, seus prepostos e das autoridades. Fato que remete à consideração de que entre a classe empírica e a classe como categoria heurística, há uma terceira dimensão da classe - a dimensão estrutural — que não é menos real, ainda que não imediata e diretamente observável como a dimensão das experiências concretas. Essa dimensão estrutural é abstrata e relacional, quer dizer, diz respeito às posições relativas que os agentes históricos concretos - identificados ou não enquanto classes - ocupam na estrutura das relações de produção. Estrutura esta que determina, no sentido de condicionar, a ação desses sujeitos, mesmo quando tal ação resulte na transformação da estrutura. Nesse sentido, a classe enquanto categoria heurística histórica diz respeito a processos históricos socialmente determinados, que transcendem as experiências individuais: processos transpessoais, transgeracionais, relacionais, isto é, inseridos em estruturas relacionais ${ }^{14}$.

A classe escrava, em toda a parte, mas no Brasil em particular, não era «rarefeita». Ao contrário, ela teve sempre uma marcada inserção na estrutura pro-

13 Essas considerações estão entre as últimas notas tomadas no cárcere, em 1934. Discutindo a história dos grupos subalternos, Gramsci as apresenta como um de seus «critérios metodológicos». Gramsci, 2002: 135.

14 O próprio Thompson, em outro texto, chamou de «mudança involuntária» as «... mudanças (...) na tecnologia, na demografia (...) cujas involuntárias repercussões afetam o modo de produção em si, alterando perceptivelmente as relações produtivas». Essas mudanças, no entanto, não reestruturam um modo de produção espontaneamente. «Talvez introduzam novas forças em cena e modifiquem a correlação de poder e riqueza entre classes sociais diversas. Mas a conseqüência da reestruturação das relações de poder, das formas de dominação e da organização social tem sempre sido um desdobramento do conflito. A transformação da vida material determina as condições dessa luta e parte de seu caráter, mas o resultado específico é determinado apenas pela luta em si mesma». «Folclore, antropologia e história social». Thompson, 2001: 262-263. 
dutiva, que condicionou os desdobramentos de suas experiências de luta. Tais experiências encontraram uma forte barreira para se condensar e passar para o plano geral. A começar pela violência intrínseca ao processo de escravização, ao desenraizamento social dos escravos e ao uso cotidiano e aberto da força para a manutenção dos cativos. Além disso, parte essencial para a perpetuação desses processos de dominação era desprover os escravos de qualquer possibilidade de desenvolvimento intelectual, moral e político mais amplo, o que era exatamente possibilitado pelas condições estruturais de existência dos escravos e pela ação dos senhores e do Estado. Isso não quer dizer que os escravos não lutassem e que não contribuíssem com suas lutas para moldar o mundo em que viviam. Mais ainda, dependendo das circunstâncias, essas experiências podiam ser «instrumentalizadas» por outros grupos sociais: trabalhadores livres, intelectuais e até mesmo setores dos grupos dominantes.

O que, no entanto, deve ser salientado e não pode ser ignorado são as particularidades das condições adversas, advindas em grande parte de sua inserção estrutural, em que os escravos viviam e travavam suas lutas. Não havia uma «mão de ferro» da estrutura que impedisse a transformação das lutas e experiências moleculares dos escravos em ação geral, política e universal. Essas condições extremamente desfavoráveis podiam — como o foram de fato no caso de Saint-Domingue - ser superadas de acordo com as circunstâncias históricas. No entanto, via de regra, não ocorreram desdobramentos como esses e o protagonismo social dos escravos sempre permaneceu subordinado. Mais ou menos ativo, mas sempre, e ao fim e ao cabo, subordinado.

Concretamente, para o século XIX, podemos considerar que tal protagonismo foi mesmo um importante fator na conformação do quadro histórico mais amplo no plano atlântico. Ele contribuiu para moldar, em alguma medida, a própria tensão antiescravista que acima foi referida. Desde a Revolução do Haiti, as rebeliões e a resistência escravas - endêmicas a qualquer sistema escravista - nunca mais foram encaradas e, principalmente, vividas pelos cativos, da mesma forma. Resistência e rebelião podiam, desde então, desembocar em revolução. Disso sabiam, diretamente, os senhores e os governos. Disso terminavam por saber, ou ao menos por vivenciar, ainda que, na grande maioria dos casos, de forma indireta, os próprios escravos.

No Brasil, nenhuma experiência de rebeldia cativa repetiu o que acontecera no Haiti. Até a década de 1880 , quando eclodiu o movimento abolicionista de massas, nenhum movimento social, protagonizado por escravos, seus descendentes ou por lideranças e outros setores de trabalhadores que se propusessem a falar em seu nome, colocou em questão a ordem escravista. Mesmo assim, diante de um protagonismo cativo, ainda que fragmentado, em um contexto político e social em que a escravidão perdia legitimidade, o temor de 
uma grande insurreição escrava foi um fantasma a atormentar senhores e autoridades, principalmente até a metade do século. Entre 1835, ano da revolta dos Malês em Salvador, e 1880, que marca o surgimento do movimento pela abolição da escravidão com a fundação da Sociedade Brasileira contra Escravidão, foram inúmeras as fugas coletivas e mesmo tentativas de revolta escravas. Em que pese o fato de que, em uma ou duas ocasiões, como, por exemplo, em Vassouras, em 1848, e em Resende, em 1881, senhores e autoridades locais tenham temido a eclosão de insurreições secretamente organizadas, estas, de fato nunca aconteceram ${ }^{15}$.

As lutas escravas, vistas retrospectivamente, continuaram a enfrentar e, em última análise, a se deter na segmentação inerente às condições sociais de vida e de trabalho dos cativos. Na época, no entanto, senhores e autoridades não correram riscos. A precaução contra uma possível insurreição escrava de largas proporções e de alcance antiescravista —uma possibilidade sempre cogitada depois do Haiti- foi um importante fator na soldagem de solidariedades escravistas para além do âmbito das vivências imediatas deste ou daquele senhor, nesta ou naquela região em particular. Em conjunto com outros fatores, esta precaução conformou, enfim, uma experiência de classe coletiva, histórica, a partir da qual os proprietários individuais de escravos passaram a viver suas vidas, a se situar no mundo das fazendas, das vilas, das cidades, mas também do Império, da Europa e da Civilização. Neste momento, em articulação com a construção do Estado, as experiências dos senhores de escravos no Brasil passaram a se dar a partir de suas vivências enquanto classe senhorial.

$$
* \quad * \quad *
$$

De qualquer forma, somente em meados da década de 1860, a questão da escravidão foi reaberta. Inicialmente, através da iniciativa do próprio imperador em nota de 14 de janeiro de 1864 a Zacarias de Góes, dissidente do partido conservador que, aliado aos liberais, assumiria a chefia do conselho de ministros no dia seguinte. Na nota, dom Pedro alertava que os acontecimentos da guerra civil norte-americana exigiam que «pensemos no futuro da escravidão no Brasil, para que não nos suceda o mesmo a respeito do tráfico dos Africanos». O imperador sugeria que se considerasse promover a liberdade dos filhos das escravas «que nascerem daqui a certo número de anos» como forma de encaminhar a questão da abolição. A referência ao que acontecera em rela-

15 Sobre 1848, ver Slenes, 2006; Salles, 2008, cap. 5. Sobre as tentativas de revoltas escravas no início da década de 1880, ver Machado, 1994: esp. cap. 2 e 3. 
ção ao «tráfico dos Africanos», quando a Inglaterra praticamente obrigara o Império, pela força de sua esquadra, a abolir o comércio internacional de cativos, é sugestiva. A situação nunca mais deveria chegar àquele ponto. A previsível vitória da União na guerra civil norte-americana e a transformação explícita do conflito naquilo que de fato ele era - uma luta de vida e morte entre um modo de vida que se nutria da escravidão e outro, que despontava como o possível vitorioso, que para se desenvolver deveria destruí-la - que era questão de tempo para que a escravidão no Brasil viesse a ser diretamente questionada no plano externo e também no plano interno ${ }^{16}$.

Pouco mais de três anos depois, em sessão de 2 de abril de 1867, agora já em plena crise de recrutamento para fazer face às necessidades de novos homens para prosseguir com a guerra contra o Paraguai, a questão entrou na pauta do Conselho de Estado. Em 28 de setembro de 1871, finalmente, depois de muitos debates e resistências, o gabinete conservador do visconde do Rio Branco fazia aprovar no parlamento a lei que libertava o ventre da mulher escrava.

Tanto a lei de 1871 — quando não mesmo a proibição do tráfico em 1850 quanto o surgimento do movimento abolicionista, no início da década de 1880 , têm sido vistos como eventos que se encaixariam em um processo gradual de abolição da escravidão. Esta perspectiva, ainda fortemente presente no que se poderia chamar de senso comum historiográfico, subestima, quando não encobre mesmo, não apenas as distâncias temporais entre estes eventos, mas principalmente suas descontinuidades políticas. Entre 1850 e 1871, decorrem duas décadas. Duas décadas de grandeza do Império e da classe senhorial, assentada sobre uma escravidão madura, consolidada, tendente a se auto-reproduzir pelo crescimento vegetativo da população escrava. A associação entre a proibição do tráfico, a lei do ventre livre e a intenção de pôr um fim, mesmo que gradual, à escravidão é uma narrativa feita a posteriori, que não estava presente na mente daqueles que se viram compelidos a tomar a primeira medida. Quanto à relação entre 1871 e 1880, a distância política é bem maior do que a distância temporal. Os abolicionistas de 1880 propuseram a abolição completa imediata, ou, inicialmente, em período muito curto, da escravidão, em larga medida, contra a lentidão e a postergação que caracterizariam do processo gradual de eliminar o trabalho escravo. Essa é uma avaliação da historiografia atual, mas também uma consideração dos próprios abolicionistas quando começaram a sistematizar suas propostas, como pode ser visto, em $O$ abolicionismo, de Joaquim Nabuco, opúsculo de propaganda publicado em 1883.

16 Salles, 2008: 89 e ss. 
Se há distâncias entre esses eventos assinalados, isso não quer dizer que eles não se inserissem em um quadro histórico geral de crise da escravidão, e nesse caso, da segunda escravidão, no hemisfério ocidental. Essa crise está intimamente relacionada com o desfecho da Guerra da Secessão, que assinalou a derrota definitiva do Sul escravista e abriu claramente a perspectiva de que o futuro de regiões escravistas mais fracas, como o Império do Brasil e a colônia espanhola de Cuba, estava comprometido. Ainda que a ameaça não fosse imediata, havia consciência, como a nota de Dom Pedro a Zacarias de Góes, acima mencionada, deixa entrever, de que a superação da escravidão era algo que tinha que ser encaminhado, sob pena de que, caso nada se fizesse, esse fim levasse consigo muito mais do que o regime de trabalho. No caso do Brasil, toda ordem social e o regime monárquico. No caso de Cuba, o estatuto colonial.

No Império do Brasil, essa crise geral da escravidão acontecia, alimentava e era alimentada por um ambiente político e social tendente à instabilidade. A partir de meados dos anos de 1860 e, principalmente, do retorno das tropas vitoriosas da Guerra do Paraguai, em fins de 1869 e início de 1870, é possível detectar claramente uma efervescência popular nas ruas do Rio de Janeiro que se prolongará por toda a década ${ }^{17}$. Não é o caso de nos determos sobre o assunto neste momento. Trata-se apenas de salientar que a Guerra do Paraguai coincidiu com a crise da hegemonia política saquarema que havia se consolidado exatamente com a substituição do gabinete conservador de 1852 pelo gabinete da conciliação, capitaneado pelo também conservador visconde do Paraná em 1853. Após a morte deste, em 1856, sucederam-se uma série de gabinetes conservadores que, em 1862, deram lugar a uma situação liberal, que se prolongou até julho de 1868. Neste momento, aproveitando-se do impasse que as forças imperiais enfrentavam na guerra, o conservador marquês de Caxias, que havia sido chamado a comandar as forças imperiais em operação no Paraguai, forçou a demissão do chefe do gabinete, Zacarias de Góes. Contra as regras não escritas, mas costumeiras da vida política até então, dom Pedro chamou o líder da minoria, ninguém menos que o saquarema Itaboraí, para formar o novo gabinete.

Este fato abriu uma crise político-institucional de dimensões sem precedentes desde o levante dos liberais da Revolução Praieira em Pernambuco, em 1848. A política, que mal ou bem, se mantinha nos limites do jogo parlamentar, transbordou novamente para as ruas. No início de agosto, formava-se o Centro Radical, cujo lema era «Reforma ou Revolução». Se a opção era pela Reforma, a menção à Revolução soava como uma ameaça velada. Não se tra-

17 Cf. Gomes, 2006, 1: 382 e ss. Ver também Soares, 1998. 
tava de afirmar que os radicais poderiam vir a pegar em armas, mas que, sem a implementação de seu programa de reformas, a situação poderia sair de controle. As bandeiras radicais - abolição do Conselho de Estado, do Senado vitalício, da Guarda Nacional e da escravidão - e a realização de conferências públicas para debater e divulgar as novas propostas deixavam claro que a população seria um componente ativo da nova política. Em diferentes localidades fundaram-se clubes radicais ${ }^{18}$. O que tudo isso mostra é que, pela via da tentativa de um renascimento liberal, principalmente como entendida por toda uma nova geração que ingressava na vida pública naquele momento, a política ia às ruas, ao mesmo tempo em que estas buscavam a política.

Durante toda a década seguinte, além do novo Partido Liberal, surgiram o Manifesto Republicano na Corte, o Partido Republicano em São Paulo, sociedades emancipadoras em diversas cidades do Império. O interior do Nordeste foi sacudido, entre 1874 e 1875 , por revoltas populares, conhecidas como o Quebra-quilos, contra a implantação do novo sistema métrico, que era visto como uma ameaça à «economia moral» da população pobre. Ainda em 1875, no interior das províncias de Minas Gerais, Rio de Janeiro, São Paulo, Espírito Santo, Bahia, Pernambuco, Alagoas, Rio Grande do Norte, Paraíba e Ceará, uma nova lei que visava a modernização do sistema de recrutamento militar, que passaria a ser feito por sorteio e que reduzia as condições de isenções até então vigentes, motivou uma série de revoltas populares. Multidões atacaram as juntas recrutadoras, rasgando suas listas e demais documentos. Em diferentes ocasiões, a justificativa era que a nova lei reduzia as pessoas livres pobres à condição semelhante à dos cativos. Do ponto de vista mais estritamente político e intelectual, um sem-número de publicações veio à luz, tratando dos mais variados assuntos e expressando diferentes pontos de vista. Não por acaso, toda uma plêiade de intelectuais que aparecia naquele momento passou a ser conhecida como a «Geração de 1870».

Em 1879, ocorreu no Rio de Janeiro a Revolta do Vintém, após o governo criar taxa no valor de um vintém sobre as passagens dos bondes, puxados por mulas. Esta cobrança causou grande reação na população da cidade, que se revolta, mata as mulas e vira os bondes. São três dias de arruaça que forçam o governo a cancelar o «imposto do vintém». Nessa revolta estão presentes algumas figuras que vão pontuar a década de 80 como agitadores populares, em particular José do Patrocínio, como tribuno do povo. Sandra Lauderdale Graham assinala que a revolta teria marcado o surgimento de uma nova cultura política urbana, em que a rua passou crescentemente a ser um local para

18 Sobre as conferências, ver Carvalho, 2007. 
se fazer política ${ }^{19}$. A Revolta não tocou no problema da escravidão, mas colocou em cena uma camada da população, que Maria Helena Machado chama de «raia miúda», que começa a se manifestar ${ }^{20}$. Existe uma suposição fundada em dados empíricos atestando que grande parte dessa camada era formada por descendentes de escravos, escravos de ganho ou negros e mestiços livres.

No Brasil imperial, a classe senhorial, até 1860, tinha praticamente o monopólio dos intelectuais e do campo intelectual. Este não era infenso à escravidão e aos escravos, mas tanto a escravidão quanto os escravos tinham impacto sobre o campo intelectual de forma indireta: pela via da pressão antiescravista e pela presença ostensiva dos cativos na vida social. $\mathrm{O}$ fato de a escravidão ter espaço no seio da própria camada intelectual, bem como a dependência direta desta camada do Estado e dos senhores contribuíam decisivamente para este fato. A partir de 1860 , esta situação começa a mudar. A camada intelectual se diversifica, diminuindo sua dependência direta do Estado e dos senhores. Mas o fato decisivo é o afastamento efetivo da camada intelectual da escravidão. $\mathrm{O}$ enrijecimento da escravidão elástica, que se caracterizava pela produção de uma camada de libertos na sociedade que antes era absorvida pelo e no mundo escravista, dificultando a absorção desta camada no seio das relações escravistas, foi decisivo para o afastamento de crescentes camadas de intelectuais do bloco intelectual escravista.

Este fato foi percebido por Gilberto Freyre, em Sobrados e mucambos, quando dedicou todo um capítulo à ascensão do mulato ${ }^{21}$. Ascensão que não se fez sem conflitos e oposição do patriarcado escravista. Mas, como notou Freyre, o fato foi percebido na própria época e transformado em relato literário em O mulato, de Aló́sio de Azevedo, publicado em 1881. Como se sabe, a obra retrata, ao mesmo tempo, a possibilidade de ascensão, e o bloqueio dessa possibilidade, de um mulato em uma sociedade cada vez mais competitiva. Em estudo sobre a cidade do Rio de Janeiro, Eulalia Lobo notou que a «proporção de libertos aumentou consideravelmente nesse intervalo de tempo [entre 1856 e 1870], deprimindo o nível salarial da mão-de-obra livre». Este segmento da população teria sido, assim, mais significativo do que a concorrência de estrangeiros neste período ${ }^{22}$.

O fato da cor, contudo, não era o elemento decisivo do processo social em curso, ainda que este não possa ser entendido em sua plenitude sem a com-

19 Graham, 1990.

20 Machado, 1994.

21 Freyre, 1996.

22 Ver Lobo, 1978, 1: 228. 
preensão desse fator. Não havia «mais» mulatos livres a partir de 1860 do que antes. Talvez - e estou consciente que me arrisco em uma contabilidade racial que pode conduzir a um beco sem saída - os houvesse até menos, se levarmos em conta o fim do tráfico africano e o aumento da imigração européia. O que havia era o nascimento do mulato enquanto categoria racialista de definição social, formativa do senso comum. Esta categoria nascia a partir de discursos intelectuais, dos quais Aloísio de Azevedo, na época, e o próprio Gilberto Freyre, mais tarde, são exemplares. O mulato e o negro substituíam categorias raciais mais afeitas à ordem escravista, tais como o pardo e o preto. $\mathrm{O}$ fator decisivo era a desagregação da ordem escravista, com o esvaziamento do éthos e do habitus senhorial-escravista. Os grupos sociais subalternos desprendiam-se e dissociavam-se da ordem escravista. Tais setores não só sempre haviam existido em larga escala, como eram formados, antes como agora, em sua grande maioria por afro-descendentes e libertos. $\mathrm{O}$ fato novo, a partir aproximadamente do final da década de 1860, é que o estar no mundo de um número cada vez maior de pessoas e categorias sociais passou a entrar em contradição com uma ordem escravista cada vez mais enrijecida e restrita aos extratos superiores da sociedade. Agora, muito poucos podiam ter escravos e nem tantos almejavam, haja vista que não podiam tê-los. Contudo, a escravidão como fonte de balizamento da ordem social continuava presente na vida de todos. Reduzida, ela nunca desapareceu das áreas urbanas ou das regiões que se organizavam fora das zonas de plantation. Escravos e livres nas áreas urbanas, especialmente na Corte, compunham um mercado de trabalho que se diversificava e se organizava em novas e mais numerosas associações mutualistas e de classe. Formava-se, assim, uma camada de trabalhadores mais vertebrada, que reivindicava interesses corporativos e direitos.

Tudo isso repercutia junto à esfera intelectual e política, angariando e atraindo o concurso de intelectuais tradicionais e, ao mesmo tempo, produzindo novos intelectuais populares, como José do Patrocínio, Luís Gama, Evaristo de Moraes e muitos outros. A escravidão aparecia, nesse momento, como questão catalizadora dessas inquietações sociais e políticas. Em 1880, não por acaso, na Câmara, Joaquim Nabuco pedia urgência para a discussão de projeto de abolição imediata. O pedido foi derrotado por 77 votos a 18 . No ano seguinte, o assunto extravasou o espaço político tradicional, a Assembléia Geral do Império. Foi criada por Nabuco, Rebouças, João Clapp, Patrocínio e outros a Sociedade Brasileira contra a Escravidão, que editava o jornal $O$ Abolicionista. No mesmo ano, surgia a Gazeta da Tarde, do abolicionista negro Ferreira de Meneses, e tinham início as Conferências Abolicionistas, organizadas pela Sociedade. «Não era ainda a rua, mas eram os teatros do Rio que se tornavam arena de luta, ampliando e democratizando o que até então se passara 
dentro do limitado espaço das Câmaras $)^{23}$. As ruas seriam ganhas e abririam seu próprio espaço logo em seguida. E depois delas, o movimento abolicionista não cessou de se ampliar socialmente, atingindo em 1887 as próprias senzalas e re-significando como experiência unificadora as lutas escravas, propondo uma nova identidade que ligasse escravos, libertos e negros e mestiços livres na busca de alargamento e mesmo conquista da cidadania.

É nesse momento que talvez pudéssemos falar da experiência de uma «classe dos homens de cor», para empregarmos uma expressão que surgia aqui e ali, principalmente no momento da Abolição e em seus desdobramentos imediatos, com repercussões até pelo menos os anos de 1930. Já na década de 1870, algumas das associações que aparecem na Corte eram de pessoas de cor, categoria que começa ser empregada com freqüência nesta altura. Podemos identificar ao menos duas delas em que a questão da cor e, indiretamente, da escravidão estava presente: a Sociedade de Beneficência da Nação Conga Amiga da Consciência, de 1872, e a Associação Beneficente Socorro Mútuo dos Homens de Cor, de $1873^{24}$. Na verdade, o pedido de entrada de reconhecimento pelo Conselho de Estado da Sociedade Beneficente da Nação Conga era de $1861^{25}$. Cabe notar que a passagem de uma associação da Nação Conga, em 1861, para outra dos Homens de Cor, em 1873, denota a importância do processo de crioulização da população escrava. Se o surgimento de associações de homens de cor não deixa de ser significativo, ele não é decisivo.

Para os trabalhadores, a escravidão não era apenas uma condição que afetava diretamente uma minoria deles. Era também uma condição que, indiretamente, terminava por deprimir as condições de trabalho de todos. Era um obstáculo básico a ser derrubado. Mas, mais importante, a luta contra o cativeiro se constituía em importante bandeira de natureza política com enorme capacidade de aglutinação de todos e, principalmente, permitia uma fácil conexão do que germinava «em baixo» na sociedade com forças políticas e intelectuais mais amplas no cenário nacional e mesmo com as correntes políticas e de opinião que circulavam em escala internacional. Não por acaso, em 1883, no opúsculo-manifesto do movimento abolicionista que buscava unificar suas bandeiras e ampliar suas fileiras, $O$ abolicionismo, Joaquim Nabuco falava do «partido do abolicionismo», enquanto uma perspectiva política, que deveria,

23 Carvalho, 1996: 1.

24 Sobre as sociedades de pessoas de cor, ver Chalhoub, 2003: 240-265. Ver também, sobre as associações mutualistas na Corte em geral, Batalha, 1999: 43-68; e ainda Viscardi e de Jesus, 2007.

25 Cf. Chalhoub, 2003: 249. 
além da própria abolição, realizar uma ampla reforma social e política, destruindo a «obra da escravidão» ${ }^{26}$.

É esse movimento abolicionista, em suas lutas concretas e suas interferências diretas nas senzalas - menos que os intelectuais ou as propostas abolicionistas-, que propiciou uma experiência unificadora para as lutas e resistências escravas ${ }^{27}$. As condições para a mudança no caráter dessas lutas - de localizadas e isoladas, com horizonte adstrito ao universo escravistaestavam dadas desde o início da década de 1870, com a alteração da correlação demográfica de forças. Esta alteração, no entanto, pode ser vista como uma causa necessária, mas não suficiente, para a eclosão do abolicionismo revolucionário em 1887. A questão decisiva foi a emergência de uma camada de intelectuais que, a despeito da configuração tradicional do campo intelectual imperial, passou a se ligar de forma cada vez mais orgânica às camadas e movimentos populares, que, por sua vez, aproximavam-se em suas vivências e experiências, dos escravos e, a partir de 1885 aproximadamente, às lutas dos próprios cativos.

Essa via formativa do movimento abolicionista na década de 1880 , por assim dizer de baixo para cima, pode ser exemplificada com o caso do Bloco de Combate dos Empregados de Padaria, instituído na Corte em 1880, e cujo lema era «Pelo Pão e pela Liberdade». O Bloco dava seguimento à luta dos padeiros que se iniciara já em 1876, diretamente ligada às condições de trabalho e à escravidão ${ }^{28}$. Neste caso, já se pode perceber a junção entre um movimento corporativo específico, típico da nova conjuntura social, com uma bandeira política por excelência, a abolição. Esboçava-se um novo «bloco intelectual» colado nas experiências de lutas populares em que a bandeira da abolição aparecia como denominador comum.

Outras formas organizativas, agora políticas, surgem em um espaço público que se populariza. Nesse sentido, podemos citar ainda o Clube Republicano de São Cristóvão, ninho de abolicionistas e que já funcionava em 1880. Entre seus membros destacados, encontramos João Clapp e o capitão Emiliano Rosa de Sena, futuro sogro de José do Patrocínio. O Clube mantinha a Escola Noturna Gratuita, «tão cheia de pessoas de cor, a maioria escravos fugidos, que a vizinhança passara a denominá-la o Quilombo da Cancela» ${ }^{29}$. Na mesma di-

26 Tratei mais aprofundadamente a relação entre o abolicionismo e a crise da hegemonia escravista em Salles, 2010.

27 A expressão é de Helen Meiksins Wood, 2003: 82, ao comentar as críticas de Perry Anderson a $A$ formação da classe operária inglesa, de E.P. Thompson.

28 Mattos, 2008.

29 Cf. Magalhães Júnior, 1969: 91-92. 
reção iam a Emancipadora Acadêmica, de 1880, e o Clube dos Libertos de Niterói, de 1881.

Estas entidades expressavam uma via «por cima» de formação do movimento abolicionista. Via que refletia e refratava o revigoramento da política, iniciado em fins da década de 1860, as «transformações moleculares» que se operavam no seio das práticas e da vida dos grupos subalternos, com a multiplicação das organizações de ajuda mútua, corporativas, mas, principalmente, todo o debate e movimentação que se acumulava no espaço público, e até mesmo nas senzalas, em torno da implementação da lei de 28 de setembro de 1871 .

$$
* \quad * \quad *
$$

Desde a aprovação da lei, começaram a surgir as primeiras sociedades emancipadoras, que tinham por fim angariar fundos para comprar alforrias de cativos. Na verdade, algumas dessas sociedades foram mesmo fundadas um pouco antes, no ambiente propiciado pela Guerra do Paraguai. Diante das dificuldades do recrutamento, escravos foram libertados, por particulares e por decisão do governo para compor as fileiras do exército. A libertação de escravos para a guerra, ainda que feita em escala muito menor do que sempre se imaginou, teve importante conseqüência simbólica. Esse ato passou a se revestir de uma clara conotação pública e patriótica. A libertação de um cativo passou a ser vista não apenas uma contribuição para o esforço de guerra, ou mesmo uma forma que alguns encontravam para evitar o recrutamento. $\mathrm{O}$ ato ganhou um significado, estimulado pelas autoridades, pela imprensa e pelo senso comum, de aprimoramento da civililidade - da cidadania, diríamos em linguagem atual-, uma vez que o homem libertado ingressava, de maneira inusitada até então, no mundo dos cidadãos, cumprindo o que se considerava o supremo dever do cidadão: a defesa da Pátria. A legislação que vedava alguns direitos políticos aos libertos continuava, entretanto, vigente. A contradição era evidente e flagrante. Neste contexto surgiram as primeiras sociedades emancipadoras, que incorporavam esse ideário civilizador.

A lei de 28 de setembro de 1871 magnificou a dimensão pública e política da libertação de escravos. A nova legislação previa a formação de um Fundo de Emancipação que deveria promover a libertação dos adultos nascidos antes de 1871. Os senhores agora tinham obrigação legal de aceitarem os pedidos de alforria daqueles que, por sua conta ou por conta de terceiros, apresentassem condições de comprá-la. Aos poucos ficou claro que tanto o Fundo de Emancipação quanto a ação das sociedades emancipadoras mal arranhavam a escra- 
vidão e o número de manumissões era insignificante. Os senhores, por sua vez, em sua esmagadora maioria, preferiam - como lhes facultava a lei- permanecer com a custódia, até que completassem 21 anos, das crianças nascidas do «ventre livre». Tudo indicava que a sobrevida da escravidão seria longa e senhores e seus representantes, que antes haviam se oposto com afinco à lei, agora a esgrimiam como justificativa para que mais nada se fizesse, uma vez que a escravidão morreria por si. A escravidão nacional passava por sua segunda reorganização (a primeira havia sido depois da proibição do tráfico internacional em 1850).

O caso da Sociedade Libertadora Cearense, pelo papel que o abolicionismo cearense viria a cumprir na configuração de um movimento nacional, é exemplar de como frustração do emancipacionismo acabou por alimentar a radicalização abolicionista. Vejamos.

Em 28 de setembro de 1879, em Fortaleza, foi fundada a sociedade Perseverança e Porvir, "sociedade de fins econômicos em moldes de cooperativa, cujos lucros, em parte, se destinam à manumissão de pretos escravizados $\rangle^{30}$. A grande maioria dos diretores e membros de destaque desta sociedade era formada por comerciantes. Vários dos membros fundadores eram republicanos. Em 1880, no primeiro aniversário da sociedade, nasceu a idéia de criação da Sociedade Cearense Libertadora, com fins exclusivos de promover a libertação de escravos; ela seria fundada ainda naquele ano, em 8 de dezembro. A presidência da nova agremiação coube a João Cordeiro, antigo empregado do barão de Ibiapaba, no Rio Grande Norte, em um estabelecimento dedicado ao comércio de escravos. Desagradado desta atividade, demitiu-se e se dirigiu ao Ceará. Tornou-se republicano e partidário da abolição da escravidão. No auxílio às vítimas da seca foi nomeado Comissário Geral dos Socorros Públicos. O vice-presidente da nova entidade era José Correia do Amaral, filho de comerciantes e proprietário rural, era também presidente da Perseverança e Porvir. A solenidade de fundação ocorreu na sede do Poder Legislativo, com o apoio do presidente da província. A boa sociedade se fez representar entre o público e entre os que discursavam. A mesma boa sociedade se fazia representar na nova diretoria, escolhida por iniciativa da sociedade fundadora Perseverança e Porvir. Tudo indicava que a Libertadora Cearense, com o fim exclusi-

30 Morel, 1988: 100, e Girão, 1969: 63. Para toda a passagem que se segue, sobre a abolição no Ceará, estarei me baseando nesses dois livros. A primeira edição do livro de Morel é de 1949, com o título O Dragão do Mar - o jangadeiro da liberdade. Morel consultou dois sobreviventes da campanha, Elvira Pinho e Alfredo Salgado, então nonagenários, e dois historiadores, Hugo Vitor Guimarães e Luiz Brigido, além de documentos inéditos e os rascunhos de um diário de Francisco José do Nascimento em poder daquele último. Morel, 1988: 47 e 49. 
vo de promover libertações pela via de emancipações pagas ou gratuitas, seguiria um caminho moderado de dar continuidade às finalidades da lei de 28 de setembro de 1871 .

Não foi o que aconteceu.

A nova sociedade imediatamente se dividiu em uma ala mais moderada, que desejava o prosseguimento da campanha de emancipações promovidas pela propaganda destinada a convencer senhores a libertarem seus cativos e pela arrecadação de fundos para a compra de alforrias, e uma ala mais radical, organizada em torno do presidente, João Cordeiro, que pregava a validade de qualquer tipo de ação que promovesse a libertação de escravos, inclusive ações diretas de facilitação de evasões. Esta ala mais radical também queria manter independência em relação ao governo. O debate se cristalizou em torno do que deveriam ser os estatutos da nova sociedade. Não houve acordo e a parte moderada abandonou a associação, permanecendo vinculada à Perseverança e Porvir. $\mathrm{O}$ episódio foi recordado mais tarde por alguns de seus participantes com ares rocambolescos. Diante do impasse, João Cordeiro forçou a aprovação de estatutos radicais: "Art. $1 .^{\circ}$ - Libertar escravos, seja por que meio for. Art. $2 .^{\circ}$ - Todos por um e um por todos $\rangle^{31}$.

$\mathrm{O}$ que teria feito a Libertadora mudar o tom do discurso e as formas de ação que tinham caracterizado as práticas emancipacionistas até então? Um radicalismo já antigo de João Cordeiro, que, não custa lembrar, seria, mais tarde, um dos republicanos jacobinos no Ceará, nos primeiros anos da República? Radicalismo que seria uma das expressões políticas ancoradas nos novos setores sociais médios, descomprometidos com a escravidão, que cresciam com a urbanização e a modernização de Fortaleza e que encontravam barreiras a sua ascensão social e política na organização tradicional do poder na província? O impacto que os efeitos sociais devastadores da seca teria trazido para estes setores? O fato de que o avivamento do comércio negreiro, aproveitando-se de uma situação calamitosa, teria acirrado antigas oposições, ao menos em termos de opinião, ao regime escravista? Será que o radicalismo de João Cordeiro e seus companheiros da Cearense Libertadora correspondia a uma percepção de que, no quadro social cearense, as ruas estavam agitadas e que era preciso falar a elas do ponto de vista da causa abolicionista, o que parece ser confirmado quando se constata as ligações entre algumas lideranças da $\mathrm{Cea}$ rense Libertadora e lideranças populares entre os marítimos, como no caso de João Cordeiro com Francisco Nascimento e, principalmente, entre Pedro Artur Vasconcelos e o liberto José Luís Napoleão?

31 Girão, 1969: 83-85. 
É difícil, se não impossível, dar uma resposta taxativa a estas questões. O mais provável é que se tratou de uma conjunção de todos esses, e outros tantos, fatores. Em fins dos anos 1870, já vimos, um abolicionismo mais radical que o emancipacionismo que até então vinha sendo praticado estava no ar. Foi a Cearense Libertadora quem primeiro captou estes novos ares.

No primeiro dia de 1881, começou a circular o jornal da nova sociedade, o Libertador, ao preço de 40 réis. A partir da máxima cristã de que os homens deveriam amar o próximo como a si mesmo, e do ideal da Revolução Francesa da liberdade, igualdade e fraternidade, conclamava, no entanto, que não vinha trazer a paz. «A liberdade só combate com a espada, porque a tirania não cede à razão e nem conhece o direito». E mais diretamente, já antecipando o que caracterizaria sua ação abolicionista em breve, declarava que «[f]icam suspensas as garantias aos potentados (...). No seu apostolado, Libertador não restringe a sua esfera de ação. Levanta o escravo e coloca o homem ao lado do homem» ${ }^{32}$. Ao lado da arrecadação de fundos, destinados a promover as manumissões, o jornal, nos seus números de 7 e 15 de janeiro e em boletins que vinham anexos à folha, passou a fazer propaganda direta contra os «negociantes de carne humana» que se dedicavam à exportação de cativos para o Sul e conclamou o povo a que impedisse esta atividade nos pontos de embarque. A Cearense $\mathrm{Li}$ bertadora, cujos membros começaram a ser perseguidos, lançou uma campanha que ficou conhecida como «Roubo de Escravos» ${ }^{33}$.

No dia 27 de janeiro de 1881, aconteceu a primeira ação patrocinada pela Sociedade Libertadora no sentido de impedir o embarque de escravos no porto de Fortaleza. Neste dia, 14 homens e mulheres seriam embarcados para os portos do Sul. Na véspera, no intervalo de uma peça teatral, o guarda-livros Pedro Artur de Vasconcelos, membro da Libertadora, lançou a idéia de apelar para os jangadeiros e capatazes do porto no sentido de que estes se recusassem a fazer o transporte dos cativos para o navio em que deveriam ser transportados para o sul. Pedro conhecia um desses jangadeiros, José Luís Napoleão, que era chefe da capatazia do porto. Napoleão havia sido escravo e, além de comprar ou obter sua própria alforria, conseguira libertar suas quatro irmãs. Era casado com «tia» Simoa, como ele, liberta. Ambos gozavam de grande prestígio na zona portuária por suas ligações com a comunidade de trabalhadores, provavelmente em sua maioria composta por pardos, caboclos e pretos - a se depreender do exemplo de suas lideranças e dos dados estatísticos do censo de 1872 que dava como brancos cerca de $39 \%$ da população livre da população

32 Citado por Girão, 1969: 86.

33 Girão, 1969: 83 e ss.; Morel, 1988: 103 e ss. 
da cidade. Dos marítimos, em 1881, muito poucos, se é que algum, ainda deveriam ser escravos. Dos 547 marítimos da província em 1872, somente 36 eram dessa condição. Em 1880, este número deveria ser ainda menor. O número diminuto de cativos, entretanto, não queria dizer que o cativeiro não fosse uma presença recente e forte na vida desses trabalhadores, como atestava a própria condição de liberto de Napoleão.

Os marítimos dispunham de uma situação privilegiada de contato com trabalhadores e notícias de outras províncias e de outras partes do mundo. Por outro lado, o contato de Pedro Artur com Napoleão também demonstra que havia uma certa intercomunicabilidade entre setores sociais de extração distinta na sociedade fortalezense. Se esses trabalhadores já estavam ou não engajados na campanha pela emancipação de escravos, é algo que não sabemos. $\mathrm{O}$ mais provável é que não, uma vez que não temos registros neste sentido, ainda que novas pesquisas historiográficas possam vir a lançar luz sobre o assunto. Que eram sensíveis não só ao tema, mas mesmo à radicalização e à transformação do que era uma campanha com ares filantrópicos em uma luta política de forte cunho social, não pode haver dúvidas. A própria idéia de buscar seu auxílio para impedir o embarque dos escravizados e sua pronta adesão à proposta o atestam. O fato é que Napoleão acolheu imediatamente ao plano, e seus companheiros também.

Napoleão, entretanto, não se considerava talhado para o papel de liderança. Ainda que não existam evidências diretas nesse sentido, é possível que sua condição social de liberto tenha pesado nessa auto-avaliação. Ele chamou para esse papel o jangadeiro Francisco José do Nascimento, o Chico da Matilde. Nascido em Aracati, na foz do rio Jaguari, filho do pescador Manoel do Nascimento e de Matilde Maria da Conceição. Mulato nascido livre, ainda menino pequeno, tornou-se, como o pai, pescador. A mãe era rendeira e o pai morreu cedo. Recebeu instrução básica tardiamente, aos 20 anos. Mudou-se para Fortaleza e se casou com Joaquina Francisca, «clara». Lá comprou duas jangadas e foi nomeado 2. ${ }^{\circ}$ prático no porto de Fortaleza em 1874. Era religioso e devoto de São Vicente de Paula, de cuja confraria foi membro. Quando participava do auxílio às vítimas da seca de 1877 a 1879, conheceu João Cordeiro.

O episódio de 27 de janeiro repercutiu imediatamente na província e mesmo no resto do Império. A campanha pela abolição na província cresceu e cedo já não se embarcavam mais escravos para o Sul. Possivelmente, própria aprovação, em seqüência, de impostos que praticamente duplicavam o preço dos cativos importados pelas assembléias provinciais do Rio de Janeiro, Minas Gerais e São Paulo, em janeiro de 1881, respondia, ao contrário do que tradicionalmente se pensa, à movimentação no Ceará. Em 1884, a província decla- 
rava que a escravidão estava extinta em seu território. Chico da Matilde, cognominado Dragão do Mar, foi trazido em triunfo, juntamente com sua jangada, para desfilar nas ruas do Rio de Janeiro, dando novo alento ao movimento abolicionista na Corte e em outras províncias.

Em quatro anos, não sem muitas lutas, enfrentamentos e, principalmente, com as fugas e rebeliões em massa de cativos em São Paulo, a escravidão estaria extinta em todo o Império.

$$
* \quad * \quad *
$$

A lei de 13 de maio de 1888, que declarou a extinção imediata, incondicional e sem indenizações da escravidão, foi um imenso triunfo do movimento abolicionista. A vitória, entretanto, teve efeitos de médio e longo prazos, em certo sentido, paradoxais. Como venho argumentando, o movimento abolicionista catalisara as lutas e experiências de escravos, libertos e livres, muitos dos quais, mas não todos, negros e mestiços, em torno da bandeira da abolição, propiciando aquilo que Ellen Woods - interpretando Thompson - chamou de «experiência unificadora», fundamental no processo de formação de classe ${ }^{34}$. Após a conquista da abolição, no entanto, essas mesmas lutas e experiências, em que pese a permanência de sociedades abolicionistas, da Guarda Negra, fragmentaram-se em outras tantas experiências e lutas, das associações e jornais dos homens de cor, certamente, mas também dos trabalhadores urbanos na construção de seus sindicatos. Tais processos, na prática, foram se distanciando, quando não se divorciando, entre outras coisas, pela ação de um certo racismo velado que se difundiu nas primeiras décadas do regime republicano, inaugurado em 1889. Assim, a possibilidade de formação de uma «classe nacional», que se esboçara na luta contra a escravidão e pela abolição, acabou não acontecendo, ao menos não em termos de dar prosseguimento às bandeiras e formas organizativas do movimento abolicionista.

Retomando as reflexões de natureza teórica sobre o conceito de classe feitas no início desse texto, pode-se dizer que somente as experiências culturais e políticas do abolicionismo não bastaram para tanto. As inserções e a dimensão estruturais das experiências de classe, que se modificaram drasticamente com a abolição e a formação de um mercado de trabalho livre, foram elementos fundamentais para embasar formações de classe de longa duração que se constituíam naquele momento.

34 Ver Wood, 2003. Ver também Thompson, 2001. 
Os trabalhos de Marcelo Badaró, Luigi Negro e Flávio Gomes, citados acima, abriram uma importante vereda de investigação, ainda por ser explorada, ao inserirem as lutas escravas na formação de uma classe trabalhadora mais ampla. Contudo, tanto no que diz respeito à compreensão das lutas escravas na conjuntura do abolicionismo, quanto no que toca à história da formação da classe trabalhadora no Brasil, eles consideraram a discussão das inserções e dimensões estruturais desse processo. O que é a classe trabalhadora que se forma então? Não é uma abstração, mas foram os operários, os artesãos, os escravos, os biscateiros, etc., que viviam suas experiências e lutavam suas lutas a partir de diferentes inserções estruturais. No processo histórico subseqüente prevaleceu a dimensão operária, que deu estofo estrutural para uma formação de classe de longa duração. Formação essa que terminou, ao menos até, grosso modo, a década de 1950, por se dar de forma distanciada do mundo dos trabalhadores rurais e das populações marginalizadas que se constituiu sobre e com os escombros da ordem escravista ${ }^{35}$.

\section{REFERÊNCIAS}

Batalha, Cláudio, «Sociedades de trabalhadores no Rio de Janeiro do século XIX: algumas reflexões em torno da formação da classe operária», Cadernos AEL, vol. 6, n. 10/11 (Campinas, 1999): 43-68.

Blackburn, Robin, A queda do escravismo colonial, 1776-1848, Rio de Janeiro, Record, 2002.

Carvalho, José Murilo de, «As conferências radicais do Rio de Janeiro: novo espaço de debate, in José Murilo de Carvalho» (org.), Nação e cidadania no Império: novos horizontes, Rio de Janeiro, Civilização Brasileira, 2007.

Carvalho, José Murilo de, «Com o coração nos lábios», introdução a José do Patrocínio, A campanha abolicionista, Rio de Janeiro, Fundação Biblioteca Nacional/Departamento Nacional do Livro, 1996.

35 Em parte, já havia esboçado essa reflexão em «As águas do Niágara» (Salles, 2010), quando considerei, seguindo Joaquim Nabuco, o abolicionismo como um partido, em sentido gramsciano, que acabou não vingando. E também em Joaquim Nabuco. Um pensador do Império, quando o considerei como um intelectual tradicional — e não orgânico - e apontei um certo impasse do que chamei de terceira geração de intelectuais imperiais que viveram a crise da escravidão, como Nabuco, Rebouças, Machado, Lima Barreto (Salles, 2002). Só que, nesses trabalhos, vi a questão do ponto de vista político e intelectual, ainda que baseado no impasse da luta abolicionista vitoriosa. Nesse texto, busquei embasar essa análise nas relações de classe que marcaram o período final da escravidão no Brasil. 
Castilho, Celso, Abolitionism Matters: The Politics of Antislavery in Pernambuco, Brazil, 1869-1888, Tese de doutorado, Universidade da Califórnia, Berkeley, 2008.

Chalhoub, Sidney, Machado de Assis: historiador, São Paulo, Companhia das Letras, 2003.

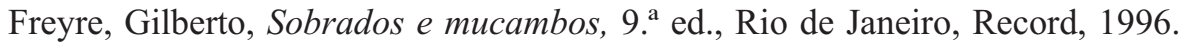

Girão, Raimundo, A Abolição no Ceará, 2. ${ }^{a}$ ed. revista, Fortaleza, Secretaria de Cultura do Ceará, 1969 (1. ${ }^{a}$ ed., 1956).

Gomes, Flávio e Antonio Luigi Negro, «Além das senzalas e fábricas. Uma história social do trabalho», Tempo social, Revista de sociologia da USP, 18/1 (São Paulo, junho de 2006): 217-240.

Gomes, Marcelo Augusto Moraes, «A espuma das províncias». Um estudo sobre os Inválidos da Pátria e o Asilo dos Inválidos da Pátria, na Corte (1864-1930), Tese de doutorado em História Social da Faculdade de Filosofia, Ciências e Letras da Universidade de São Paulo, 2006.

Graham, Sandra Lauderdale, «O motim do Vintém e a cultura política do Rio de Janeiro, 1880», Revista Brasileira de História, março/agosto, 10/20 (1990): 211-232.

Gramsci, Antonio, Cadernos do cárcere, vol. 1, Rio de Janeiro, Civilização Brasileira, 1999.

Gramsci, Antonio, Cadernos do cárcere, vol. 5, C. 25. Às margens da história (História dos grupos sociais subalternos), Rio de Janeiro, Civilização Brasileira, 2002.

Gramsci, Antonio, Quaderni del carcere, Edizione critica dell'Instituto Gramsci a cura di Valentino Gerratana, Edizione eletronica a cura dell'International Gramsci Society.

Lobo, Eulalia Maria Lahmeyer, História do Rio de Janeiro (do capital comercial ao capital industrial e financeiro), 2 vols., Rio de Janeiro, IBMEC, 1978.

Machado, Maria Helena, O plano e o pânico, São Paulo, Edusp, 1994.

Magalhães Júnior, Raimundo, A vida turbulenta de José do Patrocínio, Rio de Janeiro, Editora Sabiá, 1969.

Marquese, Rafael de Bivar; Marcia Berbel e Tâmis Parron, Escravidão e Política, São Paulo, Hucitec, 2010.

Mattos, Marcelo Badaró, Escravizados e livres. Experiências comuns na formação da classe trabalhadora carioca, Rio de Janeiro, Bom Texto, 2008.

Morel, Edmar, Vendaval da Liberdade. A luta do povo pela Abolição, 3. ${ }^{a}$ ed., São Paulo, Graal, 1988.

Salles, Ricardo, «As águas do Niágara. 1871: crise da escravidão e o ocaso saquarema», Keila Grinberg e Ricardo Salles (org.), O Brasil Imperial, v. 3, Rio de Janeiro, Civilização Brasileira, 2010. 
Salles, Ricardo, E o Vale era o escravo. Vassouras, século XIX: senhores e escravos no Coração do Império, Rio de Janeiro, Civilização Brasileira, 2008.

Salles, Ricardo, Joaquim Nabuco. Um pensador do Império, Rio de Janeiro, Topbooks, 2002.

Schmidt-Nowara, Christopher, «Empires against Emancipation: Spain, Brazil, and the Abolition of Slavery», Review. A Journal of the Fernand Braudel Center, XXXI/2 (2008): 101-119.

Schwartz, Stuart, Segredos internos: engenhos e escravos na sociedade colonial, São Paulo, Companhia das Letras, 1995.

Slenes, Robert, «A Árvore de Nsanda transplantada: cultos kongo de aflição e identidade escrava no Sudeste brasileiro (século XIX)», Douglas Cole Libby e Júnia Furtado (orgs), Trabalho livre, trabalho escravo. Brasil e Europa, séculos XVIII e XIX, São Paulo, Annablume, 2006.

Soares, Carlos Eugênio Líbano, A negregada instituição: os capoeiras na Corte imperial, 1850-1890, Rio de Janeiro, Access, 1998.

Thompson, E. P., «¿Lucha de clases sin clases?», Tradición, revuelta y conciencia de clase, Barcelona, Critica, 1989.

Thompson, E. P., As peculiaridades dos ingleses e outros artigos, org. Antonio Luigi Negro e Sergio Silva, Campinas, SP, Editora da Unicamp, 2001.

Tomich, Dale, Through the prism of slavery: labor, capital, and world economy, Boulder, Rowman \& Littlefield, 2004.

Viscardi, Cláudia Maria Ribeiro e Ronaldo Pereira de Jesus, «A experiência mutualista e a formação da classe trabalhadora», Jorge Ferreira e Daniel Aarão Reis (org.), As esquerdas no Brasil, vol. 1, A formação das tradições, 1889-1945, Rio de Janeiro, Civilização Brasileira, 2007.

Wood, Helen Meiksins, Democracia contra capitalismo. A renovação do materialismo histórico, São Paulo, Boitempo, 2003.

Fecha de recepción: 19-4-2010

Fecha de aceptación: 8-7-2010 


\section{ABOLITION IN BRAZIL: SLAVE RESISTANCE, INTELLECTUALS AND POLITICS (1870-1888)}

The Abolition of Slavery in Brazil raises the following questions: what was the social character of abolitionism? What historical meaning did it have? Was it a revolution or simply a step in the transition towards capitalism in the country? What interests did the abolition movement defend? What social groups were the movement's protagonists? What role did the slave play in the process? What did the abolitionist intellectuals defend and whom did they represent? These are the questions that lead this article to reflect on the relationship between where the intellectuals stood and the possibilities and limitations of joining forces, or the "construction» of a slave and free population as a national class at the end of the period of slavery in Brazil.

KEY WORDS: Second slavery, abolitionism, Brazil, intellectuals, social classes.

\section{ABOLICIÓN EN BRASIL: RESISTENCIA ESCLAVA, INTELECTUALES Y POLÍTICA (1870-1888)}

La abolición de la esclavitud en Brasil plantea las siguientes preguntas históricas: ¿Cuál es el carácter social del abolicionismo? ¿Cuál es su sentido histórico? ¿Fue una revolución o apenas un episodio en la transición al capitalismo? ¿Qué intereses defendia el movimiento abolicionista? ¿Qué grupos sociales protagonizan este movimiento? ¿Cuál es el papel de los esclavos en el proceso? $O$, ¿qué defendian y qué representaban los intelectuales abolicionistas? Son estas cuestiones las que guían el presente artículo, en el sentido de pensar la relación entre el lugar de los intelectuales abolicionistas y las posibilidades y los límites de la formación, o el «acontecimiento», de la población esclava y liberta en cuanto clase nacional en el periodo del final de la esclavitud en Brasil.

Palabras Clave: Segunda esclavitud, abolicionismo, Brasil, intelectuales, clases sociales. 